\title{
NEUROPROTECTIVE EFFECTS OF THE LIPIDIC EXTRACT FROM INTEGUMENT OF SQUID DOSIDICUS GIGAS
}

\author{
Pai-An Hwang \\ Seafood Technology Division, Fisheries Research Institute, Council of Agriculture, Keelung, Taiwan, R.O.C., \\ pahwang@mail.tfrin.gov.tw \\ Yi-Gung Tsai \\ Seafood Technology Division, Fisheries Research Institute, Council of Agriculture, Keelung, Taiwan, R.O.C. \\ Shu-Yun Gau \\ Seafood Technology Division, Fisheries Research Institute, Council of Agriculture, Keelung, Taiwan, R.O.C. \\ Yu-Lan Hung \\ Seafood Technology Division, Fisheries Research Institute, Council of Agriculture, Keelung, Taiwan, R.O.C. \\ Chi-Chung Fan \\ Seafood Technology Division, Fisheries Research Institute, Council of Agriculture, Keelung, Taiwan, R.O.C.
}

Follow this and additional works at: https://jmstt.ntou.edu.tw/journal

Part of the Aquaculture and Fisheries Commons

\section{Recommended Citation}

Hwang, Pai-An; Tsai, Yi-Gung; Gau, Shu-Yun; Hung, Yu-Lan; and Fan, Chi-Chung (2011) "NEUROPROTECTIVE EFFECTS OF THE LIPIDIC EXTRACT FROM INTEGUMENT OF SQUID DOSIDICUS GIGAS," Journal of Marine Science and Technology: Vol. 19: Iss. 1, Article 12.

DOI: $10.51400 / 2709-6998.2142$

Available at: https://jmstt.ntou.edu.tw/journal/vol19/iss1/12

This Research Article is brought to you for free and open access by Journal of Marine Science and Technology. It has been accepted for inclusion in Journal of Marine Science and Technology by an authorized editor of Journal of Marine Science and Technology. 


\title{
NEUROPROTECTIVE EFFECTS OF THE LIPIDIC EXTRACT FROM INTEGUMENT OF SQUID DOSIDICUS GIGAS
}

\author{
Pai-An Hwang*, Yi-Gung Tsai*, Shu-Yun Gau*, Yu-Lan Hung*, and Chi-Chung Fan*
}

Key words: Dosidicus gigas, integument, phospholipids, amyloid $\beta$-peptide.

\begin{abstract}
The integument of the squid Dosidicus gigas is an industrial waste and trouble the industrial processing. In this study, we examined the lipid composition and neuroprotective effects of D. gigas integument lipidic extract (DGI) in SH-SY5Y neuroblastoma cells which have been exposed to $\mathrm{H}_{2} \mathrm{O}_{2}$. The results showed that phospholipids, triacylglycerol and cholesterol accounted for $70.90 \pm 4.96$ (mean \pm S.D.), $20.70 \pm 3.54$ and $8.40 \pm 0.28 \%$ of DGI, respectively. And the main fatty acids were docosahexaenoic acid (30.53\% of total fatty acid), palmitic acid $(20.36 \%$ of total fatty acid) and eicosapentaenoic acid (11.84\% of total fatty acid). DGI at the concentrations of 2, 4 and $8 \mathrm{mg} / \mathrm{ml}$ successfully protected SH-SY5Y cells against the cytotoxicity, markedly increased the cell proliferation, antioxidant enzymes of glutathione contents and catalase activities, and inhibited the secretion of amyloid $\beta$-peptide 1-42. Our results suggested that DGI may be a possible approach in the prevention of Alzheimer's disease and other neurodegenerative diseases.
\end{abstract}

\section{INTRODUCTION}

The first histological clinical report of Alzheimer's disease (AD) is mentioned in 1907 [1]. The observations of patients with clinically developed AD indicate that numerous psychopathological symptoms, including intellectual dysfunctions, orientation dysfunctions, memory dysfunctions, emotional disturbances, motor and psychomotor dysfunctions, etc. [3]. These psychopathological symptoms would make AD patients lose living abilities gradually and depend on families and care-givers severely, and acting like a neonate. Up to $90 \%$ of patients with dementia developed significant behavioral problems during the course of their illness [34], however the sub-

Paper submitted 06/02/09; revised 10/28/09; accepted 02/05/10. Author for correspondence: Pai-An Hwang (e-mail: pahwang@mail.tfrin.gov.tw).

*Seafood Technology Division, Fisheries Research Institute, Council of Agriculture, Keelung, Taiwan, R.O.C. stantial proportion of patients with $\mathrm{AD}$ develop delusions or hallucinations sometimes over the course of their illness [32]. In other words, $\mathrm{AD}$ is considered simply as another form of dementia and it is common for aging individuals as well. Amyloid $\beta$-peptide $(\mathrm{A} \beta)$, an insoluble fibril deposites, is the major component of the senile plaques (SP) that characterize $\mathrm{AD}$ brain [15]. It has been demonstrated that $\mathrm{A} \beta$ is toxic directly to cultured neuron [37], and $\mathrm{A} \beta$ monomers assemble into dimmers, trimmers and higher aggregates, all of which are highly neurotoxic associated with AD [39]. $\mathrm{A} \beta$ involved on various neuronal cells surface receptors to generate reactive oxidative species (ROS), and ROS also leads to the hyperphosphorylation of Tau protein that destabilizes microtubules. This process eventually forms intracellular neurofibrillary tangles, one of observable hallmark pathology of AD [45]. In brain tissue, the level of thiobarbituric acid reactive substances (TBARS), superoxide dismutase (SOD) activity and catalase (CAT) activity are significantly decreased in AD temporal cortex when compared to age-matched controls [26]. It was observed that the sites of neurodegeneration and oxidative stress are associated with increased $\mathrm{A} \beta$ deposits in $\mathrm{AD}$ brain [19]. According to these observations, it is directly responsible for oxidative damage to neuron, leading to subsequent neuronal loss in the AD brain.

The squid Dosidicus gigas, also known as jumbo flying squid, is a commonly used by frozen seafood processing companies. Fresh squid D. gigas has a sticky consistency and their tissue is chewy. Its integument is separated from the edible part when unfrozen by hot water and treated as a fishery wastes troubling industrial processing [31]. Reportedly the phospholipids is $80-85 \%$ of total lipid in squid Ommastrephes bartrami, and docosahexaenoic acid (DHA) is a major fatty acid of total compositional fatty acid, moreover eicosapentaenoic acid (EPA) as the second [33, 10]. Numerous studies have reported that dietary DHA is required during development when cellular differentiation [7], enhanced a maze-learning ability in aged mice [24], prevention of AD [8], and reduced fish or DHA intake increases risk for AD [25]. Besides, phospholipids is a potentially useful source of $\omega-3$ polyunsaturated fatty acid, and it has showed that intestinal absorption of phospholipids is followed by preferential uptake of $\omega-3$ polyunsaturated fatty acid by the brain [27]. In animal model, 
it was also proved that DHA-enriched phospholipid diets supplement could restore DHA levels and cholinergic activity and modulate age-related alterations in hippocampus [14]. However, the action of lipidic extract from squid is still unclear, even though it is rich in $\omega-3$ fatty acid.

In this study, we are the first one to investigate the neuroprotective effect of $D$. gigas integument lipidic extract (DGI) in SH-SY5Y neuroblastoma cells which have been exposed to $\mathrm{H}_{2} \mathrm{O}_{2}$. To determine if integument of $D$. gigas could be a new resource of $\omega$-3 fatty acid enriched phospholipids, which could be prepared to a reasonable cost.

\section{MATERIALS AND METHODS}

\section{Material and Reagent}

The integument of D. gigas was kindly supplied by the Mei-er Hau Fishing Co., Ltd (Tainan, Taiwan) as refrigerated lumps. SH-SY5Y, the neuroblastoma cell line was obtained from the Culture Collection and Research Center (CCRC, Hsinchu, Taiwan), originally from the American Type Culture Collection. All other reagents used in this study were of chemical grade and commercially available.

\section{Extraction of D. gigas Integument Lipidic Extract (DGI)}

The refrigerated integument was thawed, weighed, chopped and then stirred with ten volumes of acetone for $4 \mathrm{hr}$, and filtered through a filter paper (No. 1 TOYO, Japan). After filtering, the residual integument was dried in the dryer with current air (RISEN Co., LTD, RHD-602D) at $35^{\circ} \mathrm{C}$ for $2 \mathrm{hr}$, and then the residual integument was extracted with ten volumes of ethanol for $12 \mathrm{hr}$ and centrifuged $(2,000 \times \mathrm{g}, 20$ min). The supernatants were combined, concentrated under reduced pressure at $45^{\circ} \mathrm{C}$, and DGI was obtained, and then kept it at $-20^{\circ} \mathrm{C}$ for the following tests.

\section{Lipid and Fatty Acid Composition Analyses of DGI}

Qualitative and quantitative analyses of the lipid composition present in the integument extract were performed by thinlayer chromatography (TLC) coupled to an automated flame ionization detector (FID) system (Iatroscan MK-5, Iatron Laboratories, Tokyo, Japan). Triacylglycerol (TG), cholesterol, phosphatidylethanolamine (PE), phosphatidylcholine (PC) and phosphatidylserine (PS) standards were purchased from Sigma Chemical Co. The standards and DGI were dissolved in chloroform/methanol $(2: 1, \mathrm{v} / \mathrm{v})$. The samples $(1.0 \mu \mathrm{l})$ were spotted onto silica gel-coated Chromarods (type S-III) (Iatron Laboratories) by procedure of a $2 \mu \mathrm{l}$ syringe Hamilton (Bondaluz, Switzerland) coupled to an SES 3202/IS-02 semiautomatic sample spotter (Nieder-Olm, Germany). The rods were developed consecutively four times using the following mobile phase: (1) $60 \mathrm{ml}$ of chloroform/methanol/water $/ 25 \%$ $\mathrm{NH}_{3}(47: 20: 2.5: 0.28, \mathrm{v} / \mathrm{v} / \mathrm{v} / \mathrm{v})$ up to $1 \mathrm{~cm}$; (2) $60 \mathrm{ml}$ of hexane/ diethyl ether $(63: 7, \mathrm{v} / \mathrm{v})$ up to $9 \mathrm{~cm}$; (3) $70 \mathrm{ml}$ of hexane/ benzene $(35: 35, \mathrm{v} / \mathrm{v})$ up to $10 \mathrm{~cm}$. After each development the rods were heated for $10-12 \mathrm{~min}$ at $60^{\circ} \mathrm{C}$ to dry the remaining solvent, and run through a flame ionization detector in the Iatroscan by using an air flow of $2.0 \mathrm{l} / \mathrm{min}$ atmospheric air, a hydrogen flow of $150 \mathrm{ml} / \mathrm{min}$ (high purity hydrogen, C50) and a scanning speed of $3.0 \mathrm{~s} / \mathrm{cm}$. A total scan was performed to identify all the lipid components. Data were processed with the Boreal software version 2.5. All data were analyzed in triplicate. The method was modified by Dominguez et al. [12].

DGI was prepared for fatty acid analysis according to the AOAC (FAME method) standard [16] and analyzed by capillary GC-FID (HP 5890 series II, HP-Innowax cross-linked PEG column). GC conditions were as follows: injector $250^{\circ} \mathrm{C}$, detector $300^{\circ} \mathrm{C}$, oven $210^{\circ} \mathrm{C}$, and carrier-nitrogen $1 \mathrm{ml} / \mathrm{min}$. The individual fatty acid peaks in the chromatograms were identified by comparison with authentic standards (Sigma Chem. Co.).

\section{Cell Culture}

SH-SY5Y neuroblastoma cells were grown in complete minimum essential medium (MEM) in a humidified air $/ 5 \%$ $\mathrm{CO}_{2}$ chamber at $37^{\circ} \mathrm{C}$. Sixteen hours prior to treatment cells were washed free of fetal calf serum (FCS) containing medium and further incubated in FCS-free MEM containing $\mathrm{SH}-\mathrm{SY} 5 \mathrm{Y}$ cells growth supplement $\mathrm{N}_{2}$. All cell culture materials were purchased from Gibco Life Technologies (Rockville, MD, USA).

SH-SY5Y cells $\left(2 \times 10^{5}\right)$ were treated with $50 \mu \mathrm{M} \mathrm{H}_{2} \mathrm{O}_{2}$ for $30 \mathrm{sec}$, and then treated with or without different concentrations of DGI $(2,4,8 \mathrm{mg} / \mathrm{ml})$ dissolved in $0.4 \%$ dimethyl sulfoxide (DMSO) in MEM for $24 \mathrm{hr}$. Cells treated without $\mathrm{H}_{2} \mathrm{O}_{2}$ and DGI as negative control (NC) and cells treated with $\mathrm{H}_{2} \mathrm{O}_{2}$ alone as positive control (PC). The concentration of $\mathrm{H}_{2} \mathrm{O}_{2}(50$ $\mu \mathrm{M})$ was the result of previously study which demonstrated ability to induce oxidative stress cell cytotoxicity and $\mathrm{A} \beta$ secretion [28].

\section{Cell Proliferation Assay}

Proliferation of cells was determined by streptomycin, 3-(4, 5-dimethyl thiazol-2-yl)-2, 5-diphenyltetrazolium bromide (MTT) colorimetric assay [38]. SH-SY5Y cells were washed with PBS three times and MTT $(1 \mathrm{mg} / \mathrm{ml})$ was added to the medium for $4 \mathrm{hr}$, and OD was read at $570 \mathrm{~nm}$ in an enzymelinked immunosorbent assay (ELISA) reader (Molecular Devices, Wako, Tokyo) [29]. The relative cell proliferation $\%=$ $\left(\mathrm{A}_{1} / \mathrm{A}_{0}\right) \times 100 \%, \mathrm{~A}_{0}$ was the absorbance of $\mathrm{NC}$, and $\mathrm{A} 1$ were the absorbance of DGI $(0,2,4,8 \mathrm{mg} / \mathrm{ml})$ treated with $\mathrm{H}_{2} \mathrm{O}_{2}$. The relative cell proliferation of NC was regarded as $100 \%$.

\section{Enzyme Activities Assay}

For evaluating the content of glutathione (GSH) and CAT activity, SH-SY5Y cells $\left(2 \times 10^{5}\right)$ were treated with $50 \mu \mathrm{M}$ $\mathrm{H}_{2} \mathrm{O}_{2}$ for $30 \mathrm{sec}$, and then treated with or without different concentrations of DGI $(2,4,8 \mathrm{mg} / \mathrm{ml})$ dissolved in $0.4 \%$ 
Table 1. Lipid composition of $D$. gigas integument lipidic extract (DGI).

\begin{tabular}{lr}
\hline Composition & Content* $(\%)$ \\
\hline Triacylglycerol (TG) & $20.70 \pm 3.54$ \\
Cholesterol & $8.40 \pm 0.28$ \\
Total phospholipids & $70.90 \pm 4.96$ \\
Phospholipids classes & \\
Phosphatidylcholine (PC) & $44.52 \pm 5.23$ \\
Phosphatidylethanolamine (PE) & $22.58 \pm 0.45$ \\
Phosphatidylserine (PS) & $6.80 \pm 2.35$ \\
Others & $26.10 \pm 1.69$ \\
\hline
\end{tabular}

*Mean $\pm \mathrm{SD}, \mathrm{n}=3$

DMSO in MEM for $24 \mathrm{hr}$. Cellular GSH and CAT were determined using commercial assay kit (Cayman, Catalog No. 703002 and 707002), and OD was read at 405 and $540 \mathrm{~nm}$ in an ELISA reader. All assays were performed in triplicate.

\section{Amyloid $\beta$-peptide (A $\beta)$ assay}

$\mathrm{A} \beta 1-42$ secretion was determined by a sandwich ELISA kit (Covance, Catalog No. SIG-38942). SH-SY5Y cells $\left(2 \times 10^{5}\right)$ were treated with $50 \mu \mathrm{M} \mathrm{H}_{2} \mathrm{O}_{2}$ for $30 \mathrm{sec}$, and then treated with or without different concentrations of DGI $(2,4,8 \mathrm{mg} / \mathrm{ml})$ dissolved in $0.4 \%$ DMSO in MEM for $24 \mathrm{hr}$. After incubation, cell culture medium was removed after desired time and assayed for $\mathrm{A} \beta$. The $\mathrm{A} \beta$ ELISA assay was performed in triplicate.

\section{Statistical Analysis}

The data presented are mean \pm S.D. of three determinations, and differences were considered to be statistically significant if $P<0.05$.

\section{RESULT AND DISSCUSSION}

\section{Lipid Composition of DGI}

The integument of D. gigas was tough but not fibrous. The content of DGI on dry base was $5.10 \%$, since $550.8 \mathrm{mg}$ of DGI was obtained from $10.8 \mathrm{~g}$ of dry D. gigas integument. Separation of lipid and phospholipids classes in DGI was accomplished by TLC-FID using Iatroscan technique, which was sensitive and quantitative for each lipid composition [11]. The lipid composition of DGI is given in Table 1. Phospholipids accounted for $70.90 \pm 4.96 \%$ of DGI, which was lower than the phospholipids content of total lipid in integument of squid Ommastrephes bartrami (80-85\% of total lipid) [10]. The TG and cholesterol of DGI were $20.70 \pm 3.54$ and $8.40 \pm 0.28 \%$, respectively, which were lower than phospholipids content (Table 1). It was also known that total lipid extracted from the mantle of female squid Illex argentines had a higher percentage of phospholipids and had lower sterols [30]. But the liver lipid of squid Watasenia scuntillans had high level of TG $(60.9-72.7 \%)$ [22].
Table 2. Fatty acid composition of total fatty acid in $D$. gigas integument lipidic extract (DGI)

\begin{tabular}{lc}
\hline Fatty acid & Area\% of gas chromatography \\
\hline C14:0 & 1.93 \\
C16:0 & 20.36 \\
C17:0 & 2.08 \\
C18:0 & 10.69 \\
C18:1 $(\omega-9)$ & 2.83 \\
C18:3 $(\omega-3)$ & 8.05 \\
C20:4 $(\omega-6)$ & 4.66 \\
C20:5 $(\omega-3)$ & 11.84 \\
C22:1 & 2.05 \\
C22:5 $(\omega-3)$ & 0.56 \\
C22:6 $(\omega-3)$ & 30.53 \\
Others & 4.42 \\
\hline
\end{tabular}

The major component of phospholipids in DGI was PC ( $44.52 \pm 5.23 \%$ of total phospholipids), PE $(22.58 \pm 0.45 \%$ of total phospholipids) and PS (6.80 $\pm 2.35 \%$ of total phospholipids) as follow. Our result was similar to the component of phospholipids in squid $O$. bartrami [10]. PC was found to be the main composition in the phospholipids classes of squid, such as Sthenoteuthis oualaniensis egg $(67.50 \%$ of total phospholipids) [40], Loligo vulgaris (56\% of total phospholipids) [23], and squid eye (30.7\% of total phospholipids) [43]. Generally marine oils were vulnerable to oxidation, but in comparative study on oxidative stability indicated that PC of squid eye was oxidatively more stable than PC of soybean in liposomes [43]. Besides, in oxidative stability of lipid containing phospholipids did not always decrease with increasing phospholipids contents, and stability was strongly influenced by phospholipids composition [6]. So, it was suggested that DGI may be an oxidatively stable lipidic extract of $D$. gigas integument.

\section{Fatty Acid Compositions of DGI}

The composition in terms of the important fatty acid of total fatty acid in DGI was shown in Table 2 . The main fatty acids in DGI were DHA (C22:6 $\omega-3)$ (30.53\% of total fatty acid), palmitic acid (C16:0) (20.36\% of total fatty acid) and EPA (C20:5 $\omega-3)$ (11.84\% of total fatty acid). Comprising fatty acid composition of integument of $O$. bartrami, the main fatty acids were also DHA (34.4\% of total fatty acid), palmitic acid (29.8\% of total fatty acid) and EPA (14.1\% of total fatty acid) [10]. Since phospholipids were a major composition of DGI, and total phospholipids were rich in DHA and EPA. Results implied that DGI was could be utilized as a good source of $\omega-3$ rich phospholipids.

\section{Effects of DGI on Cell Proliferation}

$\mathrm{H}_{2} \mathrm{O}_{2}(50 \mu \mathrm{M})$, a known oxidative stress inducer, which resulted in significant induction of cell cytotoxicity shown by 


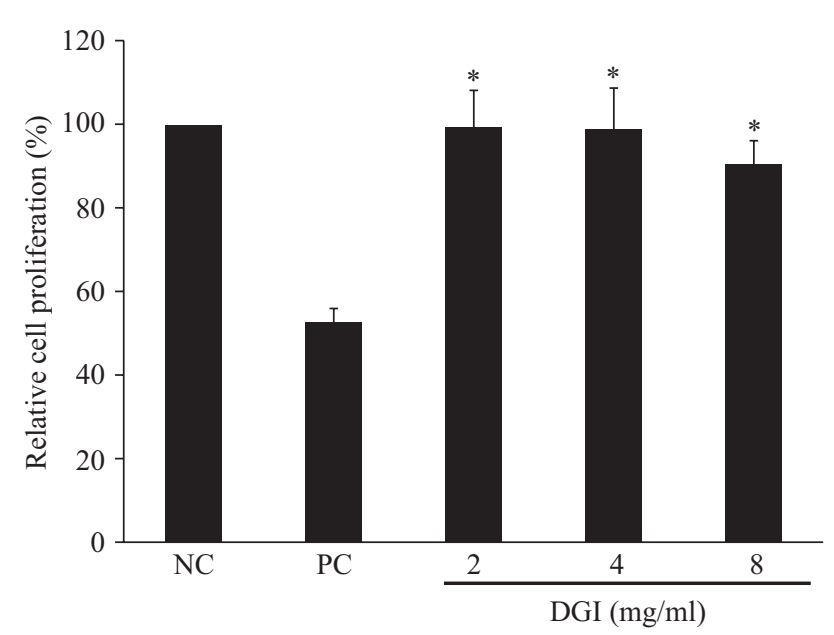

Fig. 1. Effect of $D$. gigas integument lipidic extract (DGI) on the relative cell proliferation by $\mathrm{H}_{2} \mathrm{O}_{2}$-induced $\mathrm{SH}$-SY5Y cells $(n=3)$. Means with asterisk were significantly different from the positive control $(P<0.05)$.

loss of cell viability, so we then tested whether DGI protected SH-SY5Y cells against $\mathrm{H}_{2} \mathrm{O}_{2}$-induced cell death. As determined by MTT colorimetric assay, oxidative stress by $\mathrm{H}_{2} \mathrm{O}_{2}$ resulted in a decrease of the relative cell proliferation by $52.74 \pm 2.82 \%$ (Fig. 1). DGI significantly inhibited cell death induced by $\mathrm{H}_{2} \mathrm{O}_{2}$, resulting in an increase in the relative cell proliferation of $99.57 \pm 8.29 \%, 98.95 \pm 9.67 \%$ and $90.11 \pm$ $5.42 \%$ at concentrations of 2,4 and $8 \mathrm{mg} / \mathrm{ml}$, respectively (Fig. 1). Calvert et al. [5] demonstrated that post-treatment of DHA could protect SH-SY5Y cells from glutamate-induced cell death, and DHA showed significant and dose-dependent increases in the percentage of cells with longer neurites [41, 42]. Therefore, it was suggested that DGI had inhibitory effect against oxidative stress as a result of rich in $\omega-3$ fatty acid.

\section{Effect of DGI on Antioxidant Activities}

It has been known that antioxidant system protects cells from $\mathrm{H}_{2} \mathrm{O}_{2}$, oxygen free radicals, etc. This system consisted of the enzymes GSH, CAT and SOD [13]. A decrease in the activity of any of these enzymes would most likely lead to cell death in brain [35], and AD brain is subjected to increased oxidative stress resulting from reactive oxygen species [36]. In recently clinical trials, DHA enriched phospholipids were used as neuroprotective substance [9] and $\omega$-3 fatty acid could prevent from Alzheimer's disease in animal model [8]. In an attempt to discern where DGI acted as oxidative protecting substance, we analyzed the content of GSH and the activity of CAT in follow.

The content of GSH and the activity of CAT from SHSY5Y cells were determined using ELISA kit. The content of GSH from negative control was $3.70 \pm 0.22 \mathrm{~mol} / \mathrm{g}$ protein and was markedly decreased by $\mathrm{H}_{2} \mathrm{O}_{2}$ in positive control to a level of $2.05 \pm 0.09 \mathrm{~mol} / \mathrm{g}$ protein. When DGI was added, it improved significantly the content of GSH, resulting in an increase of

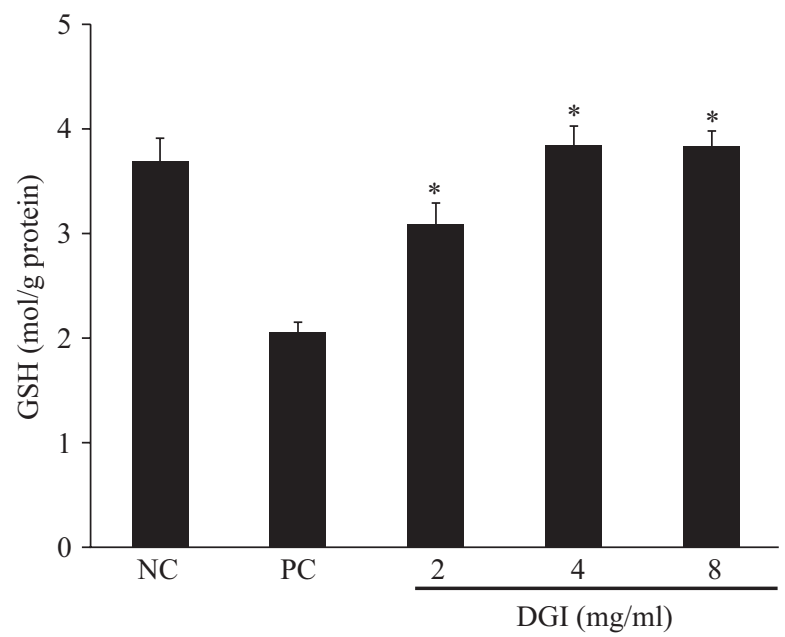

Fig. 2. Effect of $D$. gigas integument lipidic extract (DGI) on the glutathione (GSH) content by $\mathrm{H}_{2} \mathrm{O}_{2}$-induced $\mathrm{SH}-\mathrm{SY} 5 \mathrm{Y}$ cells $(\mathrm{n}=3)$. Means with asterisk were significantly different from the positive control $(P<0.05)$.

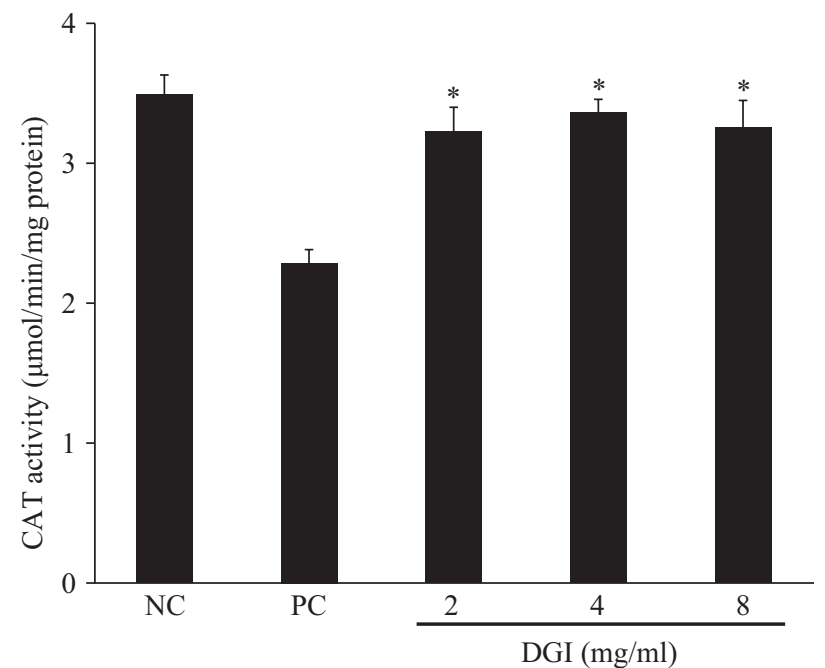

Fig. 3. Effect of D. gigas integument lipidic extract (DGI) on the catalase (CAT) activity by $\mathrm{H}_{2} \mathrm{O}_{2}$-induced SH-SY5Y cells $(n=3)$. Means with asterisk were significantly different from the positive control $(P<0.05)$.

$3.10 \pm 0.20,3.85 \pm 0.17$ and $3.84 \pm 0.15 \mathrm{~mol} / \mathrm{g}$ protein at concentrations of 2,4 and $8 \mathrm{mg} / \mathrm{ml}$ respectively, and the value was closer to negative control (Fig. 2). Similarly, cellular CAT activity was decrease by $\mathrm{H}_{2} \mathrm{O}_{2}$ from $3.5 \pm 0.14$ to $2.3 \pm 0.08$ $\mu \mathrm{mol} / \mathrm{min} / \mathrm{mg}$ protein (Fig. 3). After DGI was adding, the CAT activities improved in an increase of $3.24 \pm 0.16,3.37 \pm$ 0.09 and $3.26 \pm 0.20 \mu \mathrm{mol} / \mathrm{min} / \mathrm{mg}$ protein at concentration of 2,4 and $8 \mathrm{mg} / \mathrm{ml}$ respectively (Fig. 3). It was showed that DGI protected against $\mathrm{H}_{2} \mathrm{O}_{2}$ induced GSH and CAT loss.

Recently Kaur et al. [21] have shown that DHA acted as a neuroprotector for methylmercury-induced neurotoxicity in primary neural cell, and DHA also successfully protected 


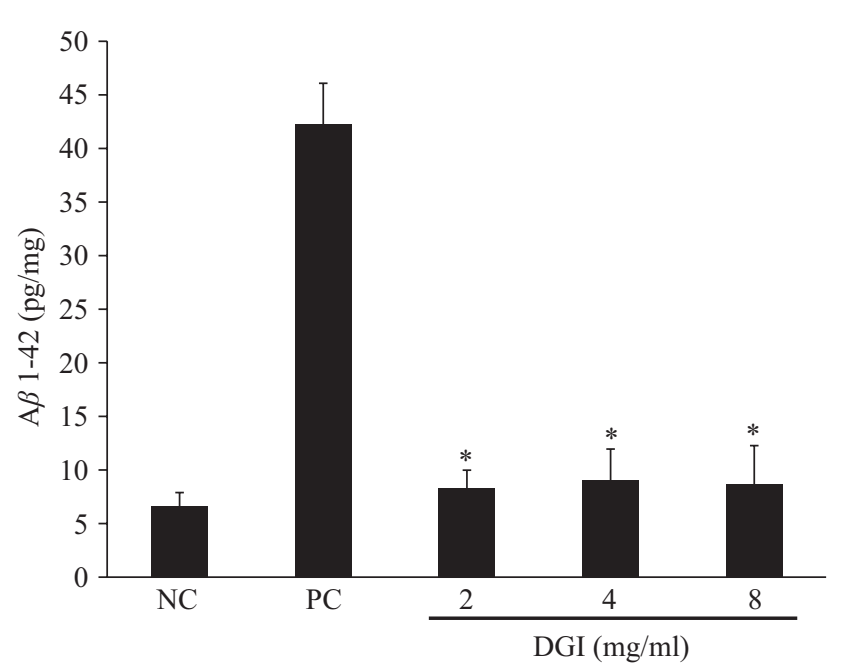

Fig. 4. Effect of $D$. gigas integument lipidic extract (DGI) on the amyloid $\beta$-peptide (A/ ) 1-42 secreation by $\mathrm{H}_{2} \mathrm{O}_{2}$-induced SH-SY5Y cells $(n=3)$. Means with asterisk were significantly different from the positive control $(P<0.05)$.

neurons against the glutamate-induced cytotoxicity, markedly increased the cell viability and the activities of glutathione peroxidase and glutathione reductase [40]. So we considered that DGI was rich in DHA, thereby DGI may be a neuroprotector for $\mathrm{H}_{2} \mathrm{O}_{2}$-induced neurotoxicity in neural cell.

\section{Effect of DGI on A $\beta$ 1-42 secretion}

$\mathrm{A} \beta$ 1-42, $\mathrm{A} \beta$ 1-40 and $\mathrm{A} \beta$ 25-35 were all toxic to cultured hippocampal neurons [44], subsequent study showed that $\mathrm{A} \beta$ 1-42 implicated for neurodegeneration in $\mathrm{AD}$ brain [4]. In order to analyze the potential anti-A $\beta$-induced neurotoxicity properties of DGI, we analyzed the level of cellular $\mathrm{A} \beta 1-42$. $\mathrm{A} \beta 1-42$ secretion from SH-SY5Y cells was $6.63 \pm 1.07 \mathrm{pg} / \mathrm{mg}$ in negative control, and was markedly stimulated by $\mathrm{H}_{2} \mathrm{O}_{2}$ to $42.30 \pm 3.65 \mathrm{pg} / \mathrm{mg}$. When DGI was added, it decreased significantly the level of $\mathrm{A} \beta 1-42$, resulting in a decrease of $8.30 \pm 1.55,9.07 \pm 2.87$ and $8.73 \pm 3.61 \mathrm{pg} / \mathrm{mg}$ protein at concentrations of 2,4 and $8 \mathrm{mg} / \mathrm{ml}$ respectively, and the values were significantly lower than positive control (Fig. 4). In addition, enrichment of culture media with DHA has been found to reduce the level of $\mathrm{A} \beta$ in PC12 neuron cells [20], and DHA also could significantly decreased the level of $\mathrm{A} \beta$ in $\mathrm{AD}$ rats [18]. EPA, another important $\omega-3$ fatty acid, acted as a precursor for DHA, which could ameliorate learning deficits associated with AD [17]. But, a contrary opinion was reported that DHA and EPA may accelerate neuronal loss in the terminal stages of prion or AD [2].

In conclusion, our study demonstrated the fact that DGI at physiological concentrations was able to protect neuronal cells from $\mathrm{H}_{2} \mathrm{O}_{2}$-induced cell cytotoxicity, oxidative stress and $\mathrm{A} \beta$ secretion for the first time. These findings were significant demonstrated that DGI may be a possible approach in the prevention of $\mathrm{AD}$ and other neurodegenerative diseases.

\section{REFERENCES}

1. Alzheimer, A., "About a peculiar disease of the cerebral cortex," In: Jarvik, L., and Greenson, H., Alzheimer Disease and Associated Disorders. pp. 7-8 (1987).

2. Bate, C., Marshall, V., Colombo, L., Diomede, L., Salmona, M., and Williams, A., "Docosahexanenoic acid eicosapentaenoic acids increase neuronal death in response to HuPrP82-146 and Abeta 1-42," Neuropharmacology, Vol. 56, pp. 934-943 (2008).

3. Bidzan, L., Pachalsaka, M., Grochmal-Bach, B., Bidzan, M., Cieslukowska, A., and Pufal, A., "Behavioral and psychological symptoms in the preclinical stage of Alzheimer's disease," Medical Science Monitor, Vol. 14, pp. 473-497 (2008).

4. Butterfield, D. A., “Amyloid $\beta$-peptide (1-42)-induced oxidative stress and neurotoxicity: Implications for neurodegeneration in Alzheimer's disease brain. A review," Free Radical Research, Vol. 36, pp. 1307-1313 (2002).

5. Calvert, G. R., Thompson, K. S. J., Martin, K. F., and Heal, D. J., "Docosahexanenoic acid affects glutamate-induced cell death in primary cortical cultures," British Journal of Pharmacology, Vol. 126, pp. 252 (1999).

6. Cho, S. Y., Joo, D. S., Choi, H. G., Nara, E., and Miyashita, K., "Oxidative stability of lipids from squid tissues," Fisheries Science, Vol. 67, pp. 738-743 (2001)

7. Clandinin, M. T., and Jumpsen, J., "Fatty acid metabolism in brain in relation to development, membrane structure, and signaling," In: Yehuda, S. and Mostofsky, D. I. (Eds.), Handbook of Essential Fatty Acid Biology, Humana Press, Totowa, New Jersey (1997).

8. Cole, G. M., Lim, G. P., Yang, F., Teter, B., Begum, A., Ma, Q., HarrisWhite, M. E., and Frautschy, S. A., "Prevention of Alzheimer's disease: Omega-3 fatty acid and phenolic anti-oxidant interventions," Neurobiology of Aging, Vol. 26S, pp. S133-S136 (2005).

9. Coste, T. C., Gerbi, A., Vague, P., Pieroni, G., and Raccah, D., "Neuroprotective effect of docesahexaenoic acid-enriched phospholipids in experimental diabetic neuropathy," Diabetes, Vol. 52, pp. 2578-2585 (2003).

10. Deng, C., Watanabe, K., Yazawa, K., and Wada, S., "Potential for utilization of the lipid and DHA-rich fatty acid of integument of squid $\mathrm{Om}$ mastrephes bartrami," Food Research International, Vol. 31, pp. 697-701 (1998).

11. Derieux, S., Fillaux, J., and Saliot, A., "Lipid class and fatty acid distributions in particulate and dissolved fractions in the north Adriatic Sea," Organic Geochemistry, Vol. 29, pp. 1609-1621 (1998).

12. Dominguez, C., Jover, E., Bayona, J. M., and Erra, P., "Effect of the carbon dioxide modifier on the lipid composition of wool was extracted from raw wool," Analytica Chimica Acta, Vol. 477, pp. 233-242 (2003).

13. Dunford, H. B., "Free radicals in iron-containing systems," Free Radical Biology \& Medicine, Vol. 3, pp. 405-421 (1987).

14. Favreliere, S., Perault, M. C., Huguet, F., De Javel, D., Bertrand, N., Pirious, A., and Durand, G., "DHA-enriched phospholipid diets modulate age-related alterations in rat hippocampus," Neurobiology of Aging, Vol. 24 , pp. 233-243 (2003).

15. Glenner, G. G., and Wong, C. W., “Alzheimer's disease: Initial report of the purification and characterization of a novel cerebrovascular amyloid protein," Biochemical and Biophysical Research Communications, Vol. 120, pp. 885-890 (1984).

16. Grimmett, C., "The use of liquid carbon dioxide for extracting natural products," Chemistry \& Industry, Vol. 15, pp. 359 (1982).

17. Hashimoto, M., Hossain, S., Tanabe, Y., Kawashima, A., Arada, T., Yano, T., Mizuguchi, K., and Shido, O., "The protective effect of dietary eicosapentaenoic acid against impairment of spatial cognition learning ability in rats infused with amyloid beta (1-40)," The Journal of Nutritional Biochemistry, Vol. 20, pp. 965-973 (2009).

18. Hashimoto, M., Shahdat, H. M., Yamashita, S., Katakura, M., Tanabe, Y., Fujiwara, H., Gamohn, S., Miyazawa, T., Arai, H., Shimada, T., and Shido, O., "Docosahexaenoic acid disrupts in vitro amyloid beta (1-40) fibrillation and concomitantly inhibits amyloid levels in cerebral cortex of Alzheimer's disease model rats," Journal of Neurochemistry, Vol. 107, 
pp. 1634-1646 (2008).

19. Hensley, K., Hall, N., Subramaniam, R., Cole, P., Harris, M., Aksenov, M., Aksenova, M., Gabbita, P., Wu, J. F., Carney, J. M., Lovell, M., Markesbery, W. R., and Butterfield, D. A., "Brain regional correspondence between Alzheimer's disease histopathology and biomarkers of protein oxidation," Journal of Neurochemistry, Vol. 65, pp. 2146-2156 (1995).

20. Johansson, A. S., Garlind, A., Berglind-Dehlin, F., Karlsson, G., Edwards, K., Gellerfors, P., Ekholm-Pettersson, F., Palmblad, J., and Lannfelt, L., "Docosahexaenoic acid stabilizes soluble amyloid-beta protofobriles and sustains amyloid-beta-induced neurotoxicity in vitro," The FEBS Journal, Vol. 274, pp. 990-1000 (2007).

21. Kaur, P., Heggland, I., Aschner, M., and Syversen, T., "Docosahexaenoic acid may act as a neuroprotector for methylmercury-induced neurotoxicity in primary neural cell cultures," Neurotoxicology, Vol. 29, pp. 978-987 (2008).

22. Kawasaki, K. I., Ooizumi, T., Hayashi, A., and Hayashi, K., "Lipid class and fatty acid composition of liver of firefly squid Watasenia scuntillans," Nippon Suisan Gakkaishi, Vol. 60, pp. 247-251 (1994).

23. Koning, A. J. D., "Phospholipids of marine origin-the squid (Loligo vulgaris)," Journal of the Science of Food and Agriculture, Vol. 61, pp. 129-132 (2006).

24. Lim, S. Y. and Suzuki, H., "Intakes of dietary docosahexaenoic acid ethyl ester and egg phosphatidylcholine improve maze-learning ability in young and old mice," The American Society for Nutritional Sciences, Vol. 130, pp. 1629-1632 (2000).

25. Maclean, C. H., Issa, A. M., Newberry, S. J., Mojica, W. A., Morton, S. C., and Garland, R. H., "Effects of omega-3 fatty acids on cognitive function with aging, dementia, and neurological diseases," Evidence Report/Technology Assessment (Summary), pp. 1-3 (2005).

26. Marcus, D. L., Thomas, C., Rodriguez, C., Simberkoff, K., Tsai, J. S., Strafaci, J. A., and Freedman, M. L., "Increased peroxidation and reduced antioxidant enzyme activity in Alzheimer's disease," Experimental Neurology, Vol. 150, pp. 40-44 (1998).

27. Mazzari, S., Zanotti, A., and Orlando, P., "Pharmacokinetics and pharmacodynamics of phosphatidylserine liposomes in mice," In: Antolini, R., Gliozzi, A., and Gorio, A. (Eds.), Transport in Biomembranes: Model Systems and Reconstitution, Raven Press, New York, pp. 257-263 (1982).

28. Olivier, G., Baysang, G., Meier, F., Muller-Spahn, F., Stahelin, H. B., Brockhaus, M., and Brack, C., "N-acetyl-cysteine protects SHSY5Y neuroblastoma cells from oxidative stress and cell cytotoxicity: effects on $\beta$-amyloid secretion and tau phosphorylation," Journal of Neurochemistry, Vol. 76, pp. 224-233 (2001).

29. Olivier, G., Novakovic, M., Savaskan, E., Meier, F., Baysang, G., Brockhaus, M., and Muller-Spahn, F., "The effects of beta-estradiol on SHSY5Y neuroblastoma cells during heavy metal induced oxidative stress, neurotoxicity and beta-amyloid secretion," Neuroscience, Vol. 113, pp. 849-855 (2002).

30. Paredi, M. E., Roldan, H. A., and Crupkin, M., "Changes in myofibrillar proteins and lipids of squid (Illex argentines) during frozen storage," Journal of Food Biochemistry, Vol. 30, pp. 604-621 (2006).

31. Ramírez-Olivas, O., Rouzaud-Sández, N. F., Haard, R., Pacheco-Aguilar, R., and Ezquerra-Brauer, J. M., "Changes in firmness and thermal behavior of ice-stored muscle of jumbo squid (Dosidicus gigas)," European Food Research and Technology, Vol. 219, pp. 312-315 (2004).
32. Schneider, L. S. and Dagerman, K. S., "Psychosis of Alzheimer's disease: clinical characteristics and history," Journal of Psychiatric Research, Vol. 38, pp. 105-111 (2004).

33. Suzuki, N., Yazawa, K., Yamada, A., Uemura, D., Kitabayashi, K., Yano, S., Fukutuka, N., and Koto, N., "Utilizationof integument of squid Ommastrephes bartrami," Proceedings of the $1^{\text {st }}$ Conference on the Marine Biotechnology, Shimizu, Japan, pp. 27 (1992).

34. Tariot, P. and Blazina, L., "The psychopathology of dementia," In: Morris, J. (Ed.), Handbook of Dementing Illnesses, Marcel Dekker, New York, pp. 461-475 (1994).

35. Terry, R. D., Masliah, E., Salmon, D. P., Butters, N., De Teresa, R., Hill, R., Hansen, L. A., and Katzman, R., "Physical basis of cognitive alterations in Alzheimer's disease," Annals of Neurology, Vol. 30, pp. 572-580 (1991).

36. Varadarajan, S., Yatin, S., Aksenova, M., and Butterfield, D. A., "Review: Alzheimer's amyloid $\beta$-pepetide-associated free radical oxidative stress and neurotoxicity," Journal of Structural Biology, Vol. 130, pp. 184-208 (2000).

37. Varadarajan, S., Yatin, S., Kanski, J., Jahanshahi, F., and Butterfield, D. A., "Methionine residue 35 is important in amyloid $\beta$-peptide-associated free radical oxidative stress," Brain Research Bulletin, Vol. 50, pp. 133 141 (1999).

38. Vittimberga, Jr. F. J., McDade, T. P., Perugini, R. A., and Callery, M. P., "Sodium salicylate inhibits macrophage TNF-alpha production and alters MAPK activation," The Journal of Surgical Research, Vol. 84, pp. 143 149 (1999).

39. Walsh, D. M., Klyubin, I., Fadeeva, J. V., Cullen, W. K., Anwyl, R., Wolfe, M. S., Rowan, M. J., and Selkoe, D. J., "Naturaly secreted oligomers of amyloid beta protein potently inhibit hippocampal long-term potentiation in vivo," Nature, Vol. 416, pp. 535-539 (2002).

40. Wang, Q., Xue, C., Li, A., and Xu, J., "Analysis of DHA-rich phospholipids from egg of squid Sthenoteuthis oualaniensis," Journal of Food Composition and Analysis, Vol. 21, pp. 356-359 (2008).

41. Wang, X., Zhao, X., Mao, Z. Y., Wang, X. M., and Liu, Z. L., "Neuroprotective effect of docosahexaenoic acid on glutamate-induced cytotoxicity in rat hippocampal cultures," Neuroreport, Vol. 19, pp. 2457-2461 (2003).

42. Wu, H., Ichikawa, S., Tani, C., Zhu, B., Tada, M., Shimoishi, Y., Murata, Y., and Nakamura, Y., "Docosahexaenoic acid induces ERK1/2 activation and neuritogenesis via intracellular reactive oxygen species production in human neuroblastoma SH-SY5Y cells," Biochimica et Biophysica Acta, Vol. 1791, pp. 8-16 (2009).

43. Yamamoto, K., Nara, E., Miyashita, K., and Cho, S. Y., "Oxidative stability and antioxidation of squid lipids," Nihon Yuka Gakkai Nenkai Koen Yoshishu, Vol. 40, pp. 127 (2001).

44. Yatin, S. M., Aksenov, M., and Butterfield, D. A., "The antioxidant vitamin $\mathrm{E}$ modulates amyloid $\beta$-peptide-induced creatine kinase inhibition and increased protein oxidation: Implications for the free radical hypothesis of Alzheimer's disease," Neurochemical Research, Vol. 24, pp. 427-435 (1999).

45. Zhang, S., Liu, J., Dragunow, M., and Cooper, G. J., "Fibrillogenic amylin evokes islet beta cell apoptosis through linked activation of a caspase cascade and JNK1," The Journal of Biological Chemistry, Vol. 278, pp. 52810-52819 (2003). 